\title{
Assessment of quality of life of type-2 diabetes mellitus patients in tertiary care teaching hospital in North India
}

\author{
Aditya Parashar ${ }^{1}$, K. K. Jha ${ }^{2}$, Arun Kumar ${ }^{1}$, Sheetal Singh Tomer ${ }^{1}$, \\ Dharmendra Singh Yadav ${ }^{1}$, Haidar Imran ${ }^{1}$
}

\author{
${ }^{1}$ Department of Pharmacy Practice, ${ }^{2}$ Department of Medicinal Chemistry, Teethanker Mahaveer College of Pharmacy, \\ Moradabad, Utter Pradesh, India
}

Received: 06 October 2019

Revised: 12 December 2019

Accepted: 13 December 2019

\section{*Correspondence:}

Dr. Aditya Parashar,

Email: adityaparashar05@gmail.com

Copyright: (c) the author(s), publisher and licensee Medip Academy. This is an open-access article distributed under the terms of the Creative Commons Attribution Non-Commercial License, which permits unrestricted non-commercial use, distribution, and reproduction in any medium, provided the original work is properly cited.

\begin{abstract}
Background: Quality of life (QoL) is a standard indicating a person's life in better condition as compared to a diseased person or patient. Diabetes itself is not a dangerous disease if managed properly, but it becomes lifethreatening after a certain time period because of the patient's poor interest in disease management and treatment adherence. Diabetes mellitus is an endocrine system disorder that invokes lack of insulin secretion in the bloodstream. The study was conducted to assess the QoL of type-2 diabetes mellitus patients with QoL instrument.

Methods: Questionnaire based cross-sectional, prospective study was conducted at Teerthanker Mahaveer Hospital, Moradabad, for a duration of 6 months from January - June 2019, on 196 patients of type-2 diabetes mellitus.

Results: On an average $56.5 \%$ people have accepted that due to the diabetic condition their working proficiency is decreased. $80.3 \%$ of patients have accepted that they were facing problems due to diabetic symptoms. Similarly, $84 \%$ of patients have accepted that the ongoing treatment was quite expensive than their expectations. Finally, the last section of the patient's emotional/mental satisfaction showed that $49.7 \%$ of patients were very satisfied with their family support while $13.7 \%$ of patients were not satisfied.

Conclusions: QOL instrument for Indian diabetes patient's instrument helped to evaluate the patient's physical strength, psychological strength of the patient during disease condition, the response provided from the family members and relatives, the economical status of the patient and its effects on their living.
\end{abstract}

Keywords: Quality of life, Patient counselling, Diabetes mellitus, Patient education

\section{INTRODUCTION}

Diabetes mellitus is an endocrine system disorder that invokes lack of insulin secretion in the bloodstream. This results in the retention of a high amount of blood glucose levels. Insulin is a hormone responsible for the facilitated diffusion of glucose from the bloodstream to the cells. The cells use this glucose to generate energy for the body to perform its normal functions. The good levels of energy are also reflected in good quality of life (QoL).
QoL is a standard reflecting a person's life in better condition as compared to a diseased person or patient. Diabetes itself is not a dangerous disease if treated properly according to the physician's advice but becomes life-threatening pertaining to over a period of time due to patient's poor interest towards disease management and treatment adherence. It starts eating the body after a threshold and makes the patient unable to work effectively. There are some organs that being affected do not work properly. Some of the vital organs being 
affected by the disease are nephrons, nerves, cardiac tissues, eyes, heart, limbs, etc.

It is a manageable disease with a healthy life style, diet and drugs/insulin therapy. Symptoms of acute diabetes are excessive urination, increased thirst, sudden weight loss, weakness, vision problems, swelling over the body, poor wound healing, etc. The factors responsible for the development of diabetes are improper food habits, sleep habits, lifestyle changes (from hardworking to sedentary lifestyle), use of antipsychotic drugs, etc. Sugarsweetened beverages: carbonated cold drinks, processed fruit juice, ice tea, energy and Vitamin water beverages may fasten the precipitation of diabetic symptoms. A period of sleep for less than 5 hours had $47 \%$ increases in incident diabetes over a 10 year period. To minimize the risk of diabetes, it is important to take 8 hours of sleep. Depression/stress is also a responsible factor. The use of antipsychotic agents has been linked with hyperglycemia and diabetes. ${ }^{1}$

Recent data has represented that 150 million people have diabetes mellitus around the world and is expected to get increased two times by the year 2025. Developing countries are at the increased risk and this change will be due to increasing population, aging, unhealthy food, overweight and sedentary lifestyle. The higher risk of disease development was found in those who were indolent, increased body weight or BMI, gluttonous and people taking high content of sweet and fatty foods. ${ }^{2}$

Diabetes is responsible for the development of renal failure, myocardial infarction, stroke, organ amputation, retinopathy and impotency. The elevated glucose levels slowly impair nephrons (structural units of the kidney) and are responsible for damaging the renal system and lost its ability to purify the blood as a regular practice. Such patients are prone to risk factors such as increased blood pressure, high serum cholesterol, obesity, etc. Diabetic neuropathy is a common complication responsible for sensory loss and damaged limbs. ${ }^{3}$

QoL is a concept having a life free from disease, mental disorder, unhappiness, pain, economic problems, working deficiency. In respect to diabetes, it represents the individual's health benefits. It also motivates the patient to improve his/her own health state as the patient is in better condition by improving own lifestyle. QOL instrument (QOLID) also helps the patients to recall all life problems, distress, suffering to another induced disorder but patient and their family members are not aware of it what happens this and why. QOLID instrument helps to measure the patient's physical strength by observing physical activities, psychological strength of the patient during disease condition followed by the response provided from the family members and relatives, economical status of the patient and its effects on their living, problems faced by the patient because of the symptoms, treatment satisfaction and the diet satisfaction during the entire disease management process. It also updates the life standards by improving health outcomes followed by treatment adherence and improvement in the treatment outcomes. ${ }^{4}$

The study objectives includes primary and secondary objective. Primary objective is assessment of QoL of patients by QoL instrument i.e. questionnaires, and secondary objective are counselling of patients to find out the easy approach for better health status in disease status. The second primary objective was to check the socio-economical and physiological condition of the patient.

\section{METHODS}

\section{Study population}

A total number of 196 type-2 diabetic patients were enrolled based on the sample size calculation and inclusion criteria. Some patients were rejected due to a fall in the exclusion criteria. All the enrolled patients had given their written consent to be a part of the study after the details of the study were described.

\section{Data collection}

Data was collected with the help of following sources such as questionnaires, patient/patient care taker interview, patient case reports, medication history of the patient, laboratory data reports and other relevant sources like medication/treatment chart/prescriptions.

\section{Study criteria}

The study was carried out by considering the following criteria:

Inclusion criteria: Adult patients of both in-patient and out-patient departments, patients diagnosed with type-2 diabetes mellitus and those who wanted to take part in the study and given consent for it.

Exclusion criteria: Patients related to other disease and those who were not interested to take part in the study.

\section{Study design}

Study type: This was a Questionnaire-based prospective and cross-sectional study.

Study place: The study was done at Teerthanker Mahaveer Hospital, Moradabad.

Study period: The study was conducted in 6 months (January to June 2019).

\section{Study procedure}

The study was started after getting approval from Teerthanker Mahaveer Medical College and Research 
Center's Institutional Ethical Committee. A well-defined data collection form and questionnaires were used to collect all the necessary information.

For extending the clinical pharmacy services in patient care, drug therapy and its outcomes were evaluated. The QOL of each patient was measured at the end of the study through Microsoft excel and manual method of simple calculation and statistical analysis.

\section{Sample size calculation}

It was calculated by using the formula:

$N=\frac{(\mathrm{Z} \alpha / 2) 2(\mathrm{SD}) 2}{E 2}=\frac{(1.96) 2(35.7) 2}{(5) 2}=196$

\section{RESULTS}

Out of total enrolled 196 patients, 91 males and 105 females participated in this study (Figure 1). The majority $(53.57 \%)$ of study participants were females. Most patients belonged to the age group of 41-60 years $(54.08 \%)$. Patient distribution on the basis of their age group was shown in the Figure 2.

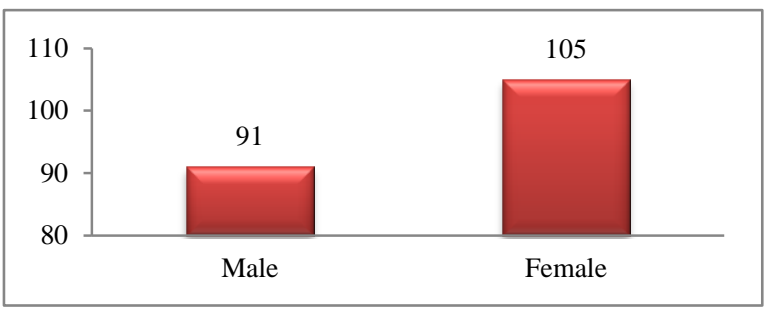

Figure 1: Detail of the patients enrolled in the study.

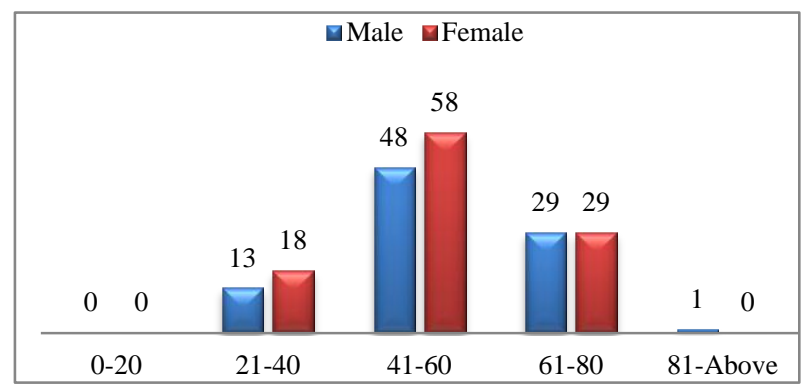

Figure 2: Segregation of the diabetic patient's distribution on the basis of their age group.

The detail of the patients on the basis of their habit/social life is shown in the Figure 3. This section includes their addiction towards smoking, alcohol consumption and tobacco chewing habits. Patients according to their occupations are distributed in the Figure 4.

\section{Working proficiency limitation due to physical health}

All patients were interviewed for their physical strength and the effect of diabetes to know about the proper knowledge of diabetes and its effects on the patient's physical activities and daily functions. The average data obtained from the patients is shown in the Table 2.

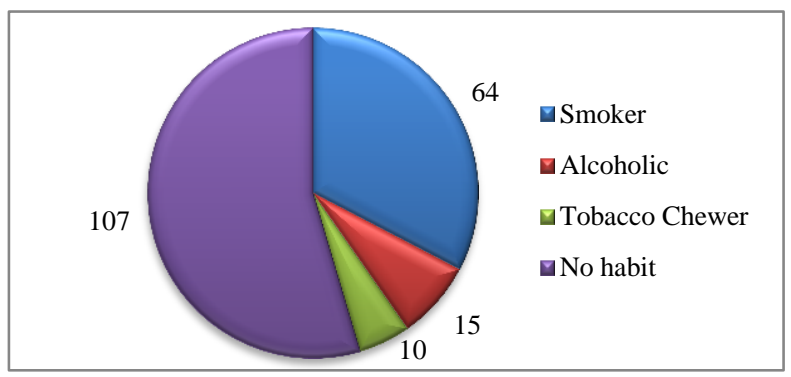

Figure 3: Segregation of the patients on the basis of social life.

Table 1: Sociodemographic data $(n=196)$.

\begin{tabular}{|c|c|c|}
\hline & $\mathbf{N}$ & Total (\%) \\
\hline \multicolumn{3}{|c|}{ Age group (in years) } \\
\hline \multirow{2}{*}{$21-40$} & Male & \multirow{2}{*}{$31(15.81)$} \\
\hline & Female & \\
\hline \multirow{2}{*}{$41-60$} & Male & \multirow{2}{*}{$106(54.08)$} \\
\hline & Female & \\
\hline \multirow{2}{*}{$61-80$} & Male & \multirow{2}{*}{$58(29.59)$} \\
\hline & Female & \\
\hline \multirow{2}{*}{ 81-above } & Male & \multirow{2}{*}{$01(0.51)$} \\
\hline & Female & \\
\hline \multirow{2}{*}{ Gender } & Male & $91(46.43)$ \\
\hline & Female & $105(53.57)$ \\
\hline \multirow{4}{*}{ Social habits } & Smokers & $64(32.65)$ \\
\hline & Alcoholic & $15(7.65)$ \\
\hline & Tobacco chewer & $10(5.10)$ \\
\hline & No habits & $107(54.50)$ \\
\hline \multirow{11}{*}{ Occupation } & Advocate & $01(0.51)$ \\
\hline & Clinician & $02(1.02)$ \\
\hline & Driver & $02(1.02)$ \\
\hline & Farmer & $25(12.70)$ \\
\hline & Govt officer & $04(2.04)$ \\
\hline & Housewives & $101(51.53)$ \\
\hline & Security guard & $01(0.51)$ \\
\hline & Shopkeeper & $10(5.10)$ \\
\hline & Student & $02(1.02)$ \\
\hline & Teacher & $01(0.51)$ \\
\hline & Worker & $47(23.90)$ \\
\hline \multirow{2}{*}{$\begin{array}{l}\text { Type of } \\
\text { drug } \\
\text { therapy }\end{array}$} & $\begin{array}{l}\text { Diet therapy, pills and } \\
\text { insulin }\end{array}$ & $21(10.71)$ \\
\hline & Diet therapy and pills & $175(89.20)$ \\
\hline
\end{tabular}

\section{Symptom botherness}

Diabetes is a disorder that directly affects the health of patients. Improper supply of glucose leads to the increased consumption of the ATPs restored in the body. Thus the body starts losing weight and the patient looks weak. On the basis of the patient's response, a table is plotted to represent different problems faced by the patients during their diabetic condition (Table 3 ). 


\section{Financial worries}

The diabetes is slow-progressing disease and is subject to be managed for a long duration. The maximum population complained about the cost of the treatment. Patients were asked about the financial burden and the data is represented in Table 4.

\section{Emotional or mental health}

In diabetic condition, the patients suffer from the decreased physical activities, financial burden and most commonly diet problem. In the meanwhile, the response of the family, friends and relatives was also a subject of interest and could be studied continuously. This section represents the data representation of the emotional/mental satisfaction of the patients in respect to the support they got from their siblings (Table 5).

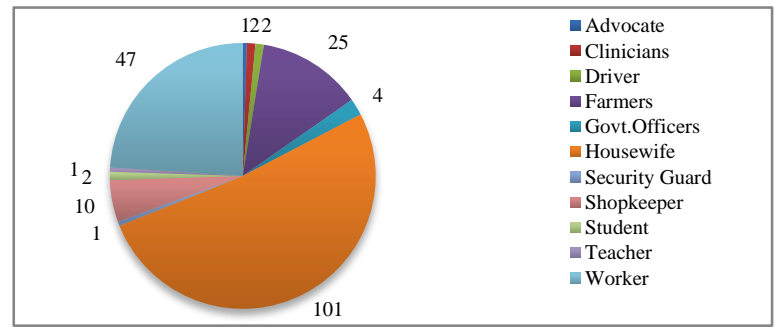

Figure 4: Segregation of the patients on the basis of occupation.

Table 2: Working proficiency limitation due to physical health.

\begin{tabular}{|lllllll|}
\hline $\begin{array}{l}\text { S. } \\
\text { no. }\end{array}$ & Questions & Always & Highly & Often & Sometimes & Never \\
\hline 1. & Because of diabetes how often miss your work. & 55 & 15 & 21 & 63 & 42 \\
\hline 2. & $\begin{array}{l}\text { A person with diabetes needs to adhere to schedule } \\
\text { eating and timely medication, how much affect your life. }\end{array}$ & 54 & 47 & 35 & 47 & 13 \\
\hline 3. & $\begin{array}{l}\text { How often your work efficiency is reduced at workplace } \\
\text { or home because of diabetes. }\end{array}$ & 56 & 37 & 51 & 40 & 12 \\
\hline 4. & $\begin{array}{l}\text { How often diabetes restricts/limiting your social and } \\
\text { family life }\end{array}$ & 56 & 43 & 51 & 31 & 15 \\
\hline 5. $\quad \begin{array}{l}\text { At what extent you avoid traveling for such purposes } \\
\text { like business/work, holiday, outing because of diabetes. }\end{array}$ & 55 & 42 & 46 & 33 & 19 \\
\hline 6. & $\begin{array}{l}\text { Compared to others of your age your social activity is } \\
\text { limited because of diabetes. }\end{array}$ & 63 & 47 & 43 & 32 & 11 \\
\hline 7. & Average patients & 56.5 & 38.6 & 41.1 & 41.0 \\
\hline
\end{tabular}

Table 3: Symptom botherness.

\begin{tabular}{|c|c|c|c|c|c|c|}
\hline S. no. & Questions & Always & Frequently & Often & Sometimes & Never \\
\hline 1. & $\begin{array}{l}\text { How frequently in the past } 3 \text { months have you observe } \\
\text { or feel excessive thirst/dry Mouth? }\end{array}$ & 39 & 79 & 41 & 30 & 07 \\
\hline 2. & $\begin{array}{l}\text { How frequently in the past } 3 \text { months have you } \\
\text { experience sudden excessive hunger because of } \\
\text { diabetes. }\end{array}$ & 11 & 74 & 45 & 56 & 10 \\
\hline 3. & $\begin{array}{l}\text { How frequently in the past } 3 \text { months have you had } \\
\text { frequent urination, difficult urination, itching because } \\
\text { of diabetes. }\end{array}$ & 09 & 88 & 41 & 46 & 12 \\
\hline 4. & Average patients & 19.6 & 80.3 & 42.3 & 44.0 & 9.60 \\
\hline
\end{tabular}

Table 4: Financial worries.

\begin{tabular}{|c|c|c|c|c|c|c|}
\hline S. no. & Questions & $\begin{array}{l}\text { Very } \\
\text { expensive }\end{array}$ & $\begin{array}{l}\text { Little } \\
\text { expensive }\end{array}$ & Reasonable & $\begin{array}{l}\text { Very } \\
\text { little }\end{array}$ & Not at all \\
\hline 1. & $\begin{array}{l}\text { What do you think about the expenditure on } \\
\text { the management of diabetes? }\end{array}$ & 86 & 72 & 35 & 03 & 00 \\
\hline 2. & $\begin{array}{l}\text { At what extant, diabetes management is your } \\
\text { priory expenditure? }\end{array}$ & 77 & 63 & 28 & 14 & 14 \\
\hline 3. & $\begin{array}{l}\text { At what extant your family budget got affected } \\
\text { because of diabetes management? }\end{array}$ & 98 & 66 & 18 & 12 & 02 \\
\hline 4. & $\begin{array}{l}\text { At what extent has your diabetes limits other } \\
\text { your expenditure. Like traveling, party, } \\
\text { enjoyment, etc. }\end{array}$ & 75 & 43 & 36 & 25 & 17 \\
\hline 5. & Average patients & 84.0 & 61.0 & 29.2 & 13.5 & 11.0 \\
\hline
\end{tabular}


Table 5: Emotional or mental health.

\begin{tabular}{|lllllll|}
\hline S. no. & Questions & $\begin{array}{l}\text { Very } \\
\text { dissatisfied }\end{array}$ & $\begin{array}{l}\text { Moderate } \\
\text { dissatisfied }\end{array}$ & $\begin{array}{l}\text { Neither } \\
\text { satisfied nor } \\
\text { dissatisfied }\end{array}$ & $\begin{array}{l}\text { Moderate } \\
\text { satisfied }\end{array}$ & $\begin{array}{l}\text { Very } \\
\text { satisfied }\end{array}$ \\
\hline 1. & How satisfied are you with yourself? & 11 & 17 & 33 & 51 & 84 \\
\hline 2. & $\begin{array}{l}\text { How satisfied are you with your } \\
\text { personal relationships. }\end{array}$ & 09 & 14 & 25 & 55 & 41 \\
\hline 3. & $\begin{array}{l}\text { Is you are getting emotional support } \\
\text { from family and friends, then how } \\
\text { satisfactory. }\end{array}$ & 18 & 48 & 79 & 410 \\
\hline 4. & $\begin{array}{l}\text { How often are you discourage your } \\
\text { health problems? }\end{array}$ & 17 & 106 & 39 & 22 & 12 \\
\hline 5. & Average patients & 13.7 & 46.2 & 44.0 & 42.2 & 49.7 \\
\hline
\end{tabular}

\section{DISCUSSION}

QoL acts upon some of the vital and important aspects of the patient's life. Assessment of QoL is an important phenomenon for the improvement in diabetic patient's life. In our study, we assessed the diabetic patients with a defined set of questions. A total number of 4 sets of questions of different activities were used. According to the patient's knowledge about the disease, they were given a choice to select any option from multiple-choice questions.

In our study, total numbers of 196 patients were enrolled on the basis of inclusion and exclusion criteria. The sample size was calculated mathematically with statistical methods. Socio-demographically, female population was $105(53.57 \%)$ and the male population was 91 (46.43\%). The highest population fell in 41-60 years age-group having 106 patients $(54.08 \%)$, followed by $61-80$ years age-group having 58 patients $(29.59 \%)$ and $21-40$ years age-group having 31 patients $(15.81 \%)$. A significant number of patients $64(32.65 \%)$ had a habit of smoking. People from almost all professions were enrolled in the study. Among highest were the housewives 101 (51.53\%), followed by the worker, farmer, advocate, teacher, etc. In this study, we received most of the patients with diet therapy and pills $175(89.28 \%)$ and rest with diet therapy, only pills and insulin as their treatment regimen.

During the assessment of QoL, we found a large no. of patients not aware of the health facilities, treatment and life style modification. Firstly, most of the patients had poor working proficiency. The second set of questions about the symptoms bothered, patients were not taking attention to symptoms of T2DM. Only a few educated diabetic patients were paying attention to the symptom bothered. Housewives were found not bothered about symptoms. In our hospital, mostly diabetic patients belonged to the rural areas and worked as labor. Treatment was not at all expensive for only $11 \%$ of diabetic patients, while for the rest it was expensive.

Similarly, $84(42.86 \%)$ of diabetic patients had financial worries because of the medication and treatment expenses. About $49.7 \%$ of patients were emotionally or mentally satisfied with their ongoing welfare and treatment. In this group, patients were financially independent as they were getting good support from their families. Whereas $46.2 \%$ of patients were dissatisfied towards the QoL because of the support and aid they got from their respective families and relatives. Most of the geriatric patients were largely dissatisfied with their family support.

Previous studies held on this topic QoL in diabetic patients done by a WHO questionnaires or any similar questionnaires they generate results accordingly and modeled basis. If we compare our study with previous studies our study was more appropriate than other studies because our study was done by specially prepared questionaries' [QOLID: a validation and reliability study in middle and higher income groups by Sitaram Bhartiya Institute] for North India region. North Indian people's food habits are quite different than other areas of India. ${ }^{4}$ SF- 36 or any other questionaries' are generally prepared for whole of the world or Asian region. Our study quantitatively measured QoL through questions related to pain, behavior, anxiety, working conditions, problems in daily working, regularity and other questions that accurately measure QoL.

While a study was conducted by Mosadu et al on diabetic demographic condition like age and their effect on glycemic control. ${ }^{7}$ They found that whenever age goes above 40 people loss their glysemic control, more reduction in QoL.

Another study was conducted by Issa et al on topic of evaluation of health related QoL with HRQoL questionnaires, sample size was 200 and results summarise as mean score of 63.1 on ranging from 61.565.5 on sub scale. The diabetic related complications, duration of diabetes, mental status are significantly associated with HRQoL. ${ }^{6}$

Shaheen conducted a study with the help of SF-36 questionnaires, a cross sectional study on OPD patients. ${ }^{8}$ Total 209 patients were enrolled in this study. Absorbed about mean age of diabetes, (49.12), mean duration of diabetes, further study results shows male having more 
complication than females. Conclusion of the study has shown the better QoL of females than males.

Ramlingam et al conducted a study of KAP basis and take outcome as knowledge attitude and practice basis. It was knowledge improving study and the results has shown a good improvement in knowledge, attitude and practice towards diabetes and glysemic control. ${ }^{5}$

\section{CONCLUSION}

QoL is improved by following a managed life-style because diabetes cannot be cured completely, it can only be managed by certain things like life-style modification, taking balanced diet, proper sleep, regularity in drugs and insulin intake, etc. Mismanagement can cause the moderate to severe health issues. Good QoL is a line of choice for every diabetic patient. T2DM has accounted for more than $90 \%$ of the cases of diabetes making it a severe health issue. QoL is a standard to live a life in a manner which includes stress-free, without pain, without any acquired and co-morbid condition. In other words, diabetes can be managed by different human efforts and some medical procedure imparted various health care professionals because their knowledge and skills are helpful to obtain a well-defined health condition and improvement in the patient's QoL respectively. In our study, the population from various professions involved drivers, security guards, government officers, teachers, students, workers and housewives. Patients were also questioned about their social life in order to know deeply about their habits of smoking, alcohol consumption, tobacco chewing, etc. QOLID instrument helped to measure the patient's physical strength by observing physical activities, psychological strength during disease condition followed by the response provided from the family members and relatives, economical status of the patient and its effects on their living, problems faced by the patient because the symptoms, treatment satisfaction and the diet satisfaction during the entire disease management process. It also updates the life standards by improving health outcomes followed by treatment adherence and improvement in the treatment outcomes. Our study will help the patients to improve their QoL and the learners to study further in order to assess the patient's knowledge, attitude and practice between different professional groups specially in middle and higher income groups in North India region.

\section{ACKNOWLEDGEMENTS}

Authors would like to thank the Department of Pharmacy Practice, Teerthanker Mahaveer College of Pharmacy and Teerthanker Mahaveer Hospital including their medical staff and other healthcare professionals for providing untoward support for conducting this study.
We extend acknowledgment to Dr. Jitender Nagpal and his team, Sitaram Bhartia Institute of Science and Research, New Delhi for meaningful work in the development of the QOLID instrument. We would like to thank all the Institutional Ethics Committee members and healthcare professionals of TMMC\&RC, TMU, Moradabad, comprising of caregivers and clinical pharmacists for their aid to contribute reliable information for successful accomplishment of the study.

Funding: No funding sources

Conflict of interest: None declared

Ethical approval: The study was approved by the Institutional Ethics Committee

\section{REFERENCES}

1. Kumar SA, Koppad R, Chandrashekar V, Revathy. "Quality of Life" of Type-2 Diabetes patients in a tertiary care hospital in southern part of India, Shimoga Karnataka. Int Community Med Public Health. 2016;3(7):1723-8.

2. Holt RIG, Barry GJ. "Textbook of Diabetes", Wiley Blackwell Publication, New Jersey, USA. 2017 March; Edition. 2017: 34-37.

3. Issa BA, Baivewu O. A cross-sectional study on "Quality of Life" of T2DM in a Nigerian teaching hospital. Hong Kong Psychiatr. 2006;6(1):27-33

4. Nagpal J, Kumar A, Kakar S, Bhartia A. The Development of 'Quality of Life Instrument for Indian Diabetes Patients (QOLID): A Validation and Reliability Study in Middle and Higher Income Groups. 2010;58:295-304.

5. Ramlingam N, Sirvarajan KS, Muhammad P, Ganeshan B. Study on the impact of patient counseling in improving QoL in Diabetic patients. 2017;6(8):646-8.

6. Issa BW. Evaluation of health related QoL of Emirati people with Diabetes: Integration of sociodemographic and disease related variables. WHO. 2011;17(11):825-30.

7. Al-Maskari MY, Al-Shookri AO, Al-Adawi SH, Lin KG. Assessment of quality of life in patients with type 2 diabetes mellitus in Oman, Saudi Med J. 2011;32(12):1285-90.

8. Shaheen F, Basit KA, Riaz M, Fawwad A, Hakeem R, Basit A. Assessing Health Related Quality Of Life In Diabetic Subjects By Sf 36 Questionnaire In A Tertiary Care Diabetes Unit Of Karachi, Pakistan. Int J Adv Res. 2014;2(6):13-7.

Cite this article as: Parashar A, Jha KK, Kumar A, Tomer SS, Yadav DS, Imran H. Assessment of quality of life of type-2 diabetes mellitus patients in tertiary care teaching hospital in North India. Int $\mathbf{J}$ Basic Clin Pharmacol 2020;9:107-12. 